\title{
Reflectieve professionaliteit. Naar een invulling van het CCMS-competentiegebied 'professionaliteit"
}

\author{
M.A. Verkerk, M. de Bree, Fr. Jaspers
}

\section{Samenvatting}

In de komende jaren worden in Nederland de opleidingen van arts-assistenten geherstructureerd. Hierbij wordt een algemeen competentieprofiel voor medisch specialisten gebruikt, dat vrijwel identiek is aan de Canadese CanMEDS-rollen. De CanMEDS-rollen beschrijven zeven algemene competentiegebieden van de medisch specialist. Eén daarvan is professionaliteit. Om mede op basis van dit competentiegebied een opleiding vorm te geven, is het noodzakelijk een visie te ontwikkelen die recht doet aan de medische praktijk van alledag. De twee belangrijkste visies op professionaliteit (professionaliteit opgevat als kwaliteit van karakter of als kwaliteit van gedrag) schieten wat dat betreft tekort. Alleen professionaliteit opgevat als reflectieve professionaliteit biedt ruimte aan de fundamentele contextgebondenheid van medisch handelen. Voor opleiding en toetsing betekent dit dat de focus verschuift naar het verantwoorden van het handelen. (Verkerk MA, Bree M de, Jaspers Fr. Reflectieve professionaliteit. Naar een invulling van het CCMS-competentiegebied 'professionaliteit'. Tijdschrift voor Medisch Onderwijs 2005;24(4):162-167.)

\section{Inleiding}

De komende jaren gaat het een en ander veranderen binnen de opleidingen van arts-assistenten. Het Centraal College Medische Specialismen (CCMS) heeft in het kader van de vernieuwing van de specialistenopleidingen besloten tot invoering van een algemeen competentieprofiel voor medisch specialisten. Dit profiel is gebaseerd op de Canadese CanMEDS-rollen. Het beschrijft zeven algemene 'competentiegebieden', die elk weer bestaan uit enkele algemene kerncompetenties. Deze zeven competentiegebieden zijn: medisch handelen, communicatie, samenwerking, kennis en wetenschap, maatschappelijk handelen, organisatie en professionaliteit.

Het vertalen van de kerncompetentiegebieden naar een opleiding is echter allerminst eenvoudig. Dit geldt met name voor het competentiegebied 'professionaliteit'.
Het CCMS heeft ervoor gekozen om dit competentiegebied in te vullen met vier kerncompetenties die met name in gedragscriteria zijn omschreven (zie tabel 1). Voor het overige biedt de omschrijving van het CCMS echter nog weinig handvatten over hoe professionaliteit op een zinnige en effectieve manier binnen een opleidingsprogramma geïntegreerd kan worden. ${ }^{1}$ Hiervoor is het nodig een coherente visie op professionaliteit te ontwikkelen die recht doet aan het verschijnsel professionaliteit in de medische praktijk. Hieronder presenteren wij een dergelijke visie, welke als basis kan dienen voor het ontwerp van scholings- en toetsingsprogramma's voor arts-assistenten.

Wij zien professionaliteit als een complexe praktijk waarin 'verantwoording' ('accountability') als belangrijkste kerncompetentie wordt gezien. ${ }^{2-3}$ We zullen uiteenzetten waarom ons inziens profes- 
sionaliteit moet worden opgevat als een tweede orde competentie - een competentie die alleen tot uitdrukking kan komen in de uitoefening van andere competenties. Tot slot zullen we kort de consequenties van deze visie bespreken voor zowel opleidings- als toetsingsprogramma's. Met betrekking tot dit laatste zullen we ons vooral richten op opleiding en toetsing van wat we zullen noemen de reflectieve en morele component van professionaliteit. We beginnen echter met het bespreken van enkele gangbare opvattingen over professionaliteit.

Figuur 1. De CCMS-omschrijving van het competentiegebied 'professionaliteit'.

\section{Professionaliteit:}

1.1 De specialist levert hoogstaande patiëntenzorg op integere, oprechte en betrokken wijze.

De specialist vertoont adequaat persoonlijk en interpersoonlijk professioneel gedrag.

1.3 De specialist kent de grenzen van de eigen competentie en handelt daar binnen.

De specialist oefent de geneeskunde uit naar de gebruikelijke ethische normen van het beroep.

\section{Professionaliteit}

Uit de literatuur komen twee belangrijke opvattingen over professionaliteit aan de orde: professionaliteit wordt óf als een kwaliteit van gedrag opgevat, óf als kwaliteit van karakter of persoon. ${ }^{4-5}$ Als professionaliteit wordt opgevat als kwaliteit van gedrag, worden er normen aangelegd waar gedrag te allen tijde aan moet voldoen. Er is verschil van mening over de vraag of professioneel gedrag als een aparte categorie moet worden gezien of als een onderdeel van het klinisch handelen. Zo kiest het projectteam Consilium Abeundi ervoor om professioneel gedrag op te vatten als eigenstandige categorie met als onderscheidende dimensies: omgaan met taken/werk, omgaan met anderen en omgaan met zichzelf. ${ }^{6}$

Bij professionaliteit als kwaliteit van $k a-$ rakter of persoon ligt de focus op persoonlijkheidsvorming. Het gaat dan om het opleiden van assistenten tot 'the right person doing it'. ${ }^{7}$ Vooronderstelling is dat een goed karakter een dominante sturende factor is bij het tot stand komen van gedrag. Een arts die professioneel is, zal automatisch ook professioneel handelen. Een arts-assistent is professioneel wanneer hij of zij bijvoorbeeld empathisch of plichtsgetrouw is en bijgevolg daar ook naar handelt. Ook het CCMS refereert in de beschrijving van het competentiegebied 'professionaliteit' aan persoonlijke karakteristieken als integriteit, oprechtheid, betrokkenheid en plichtsgetrouwheid (overeenkomstig de beroepsmoraal). Overigens worden bij het beoordelen van professionaliteit beide opvattingen - professionaliteit als kwaliteit van gedrag en als kwaliteit van persoon - vaak wel direct met elkaar verbonden. Voor de beoordeling van professionaliteit staat het observeerbare gedrag centraal, waarbij gedrag als zichtbare buitenkant wordt gezien van de (innerlijke) persoonlijke karakteristieken van de professional. Doordat het beoordelen van professionaliteit uiteindelijk neerkomt op het beoordelen van waarneembare fenomenen, wordt getracht een zekere mate van objectiviteit in de beoordeling te borgen.

Probleem met beide visies is echter dat zij onvoldoende recht kunnen doen aan de contextuele afhankelijkheid van professionaliteit. Ginsburg et al. waarschuwen in dit verband voor de 'fundamentele at- 
tributiefout': een onderschatting van de invloed van de omgeving op gedrag, gepaard aan een overschatting van het idee dat gedrag de resultante is van attitudes of karaktertrekken van het individu. ${ }^{8}$ Dit doet zich bijvoorbeeld voor bij de toetsing van professionaliteit. Wie bepaalt immers de maatstaf aan de hand waarvan de oprechtheid of betrokkenheid van de assistent wordt gemeten? Ook is het voorstelbaar dat opleiders (deels) verschillende maatstaven hanteren. Deze zijn immers onderhevig aan sociale en culturele, maar ook aan professionele diversiteit. ${ }^{9}$

Op nog een heel andere manier is het betrekken van de context bij de beoordeling van professionaliteit van belang. Uit onderzoek blijkt dat de omgeving waarin de arts-assistent werkt van grote invloed is op het individuele gedrag. Door uitsluitend te focussen op het individuele professionele gedrag of karakter van de arts-assistent blijft de omgeving als professionele praktijk onbelicht. Dat is problematisch gegeven de socialiseringseffecten van die omgeving. Socialisering van arts-assistenten uit zich niet zelden in de vorming van een medisch-technisch personage; ${ }^{10}$ assistenten wordt geleerd dat professioneel gedrag vooral klinische distantie vraagt. Accurate observatie en besluitvorming in de geneeskunde vragen immers om objectiviteit. Clinici zijn voor het medisch technische domein, daar ligt hun expertise. Voor zover betrokkenheid bij de patiënt een thema van belang is, heeft die het karakter van klinische distantie: "Wat wij dokters vooral moeten doen, is het behandelen van patiënten; praten moeten patiënten met anderen doen.” Zolang artsassistenten in een dergelijke omgeving worden opgeleid, zullen zij zich snel voegen naar de mores van die afdeling en hun leermeesters. Iedere verdere opleiding in professioneel gedrag loopt dan de kans als obligaat en niet ter zake doende te worden afgehandeld. Voor het aanleren van professioneel gedrag is het dus ook van belang te kijken naar de omgeving waarin gedrag wordt aangeleerd en in het bijzonder naar de cultuur van die omgeving. ${ }^{11}$

Professionaliteit en de beoordeling daarvan vinden daarom altijd plaats in een specifieke context en praktijk. ${ }^{5}$ Dit betekent ten eerste dat voor de beoordeling en waardering van professioneel gedrag het noodzakelijk is dat de beoordelaar (opleider) zich niet alleen verantwoordt voor de beoordeling zelf, maar ook voor de vaak impliciet gehanteerde maatstaven daarin. Dit laatste heeft ook gevolgen voor de training van opleiders van arts-assistenten. Immers ook opleiders dienen zich bekwaam te tonen in het beoordelen van professionaliteit als een competentie in context.

Naast dit probleem van de ongegronde normstelling is het betrekken van de context nog op een tweede manier van belang. Beide eerder beschreven visies op professionaliteit doen geen recht aan wat in de beroepspraktijk zelf onder professionaliteit wordt verstaan. Neem bijvoorbeeld een situatie waarin een arts niet de waarheid vertelt aan een patiënt. Indien professionaliteit wordt opgevat als kwaliteit van gedrag of karakter, dan moet deze handeling in alle gevallen als onprofessioneel worden beoordeeld - hetzij omdat de assistent niet over een belangrijke karaktereigenschap beschikt (eerlijkheid), hetzij omdat het gedrag niet aan de gangbare beroepsnormen voldoet.

Toch zijn er situaties denkbaar waarin het juist wel professioneel is om als arts een patiënt de waarheid niet te vertellen of voor een leugentje om bestwil te kiezen. Als een arts onomwonden een zeer slechte prognose aan een patiënt meedeelt die daar op dat moment nog helemaal niet aan toe is, dan zet dat vraagtekens bij zijn 
of haar professionaliteit. Binnen de kaders van de twee gangbare visies is echter niet goed uit te leggen waarom dit het geval is; er is immers geen ruimte voor contextafhankelijke beoordeling. Onvoldoende wordt ingezien dat professionaliteit juist te maken heeft met het verantwoorden van gemaakte keuzes en beslissingen in situaties waarin conflicterende waarden en normen op de voorgrond staan. ${ }^{10}$ Niet zelden wordt een arts geconfronteerd met een situatie waarin een keuze moet worden gemaakt tussen het vertellen van de waarheid en het geven van hoop aan de patiënt. Wat de keuze zal zijn, hangt af van de specifieke situatie waarin die vraag opkomt en is niet op voorhand te geven. Artsen uiten hun professionaliteit op het moment dat zij zich bewust tonen van dergelijke conflicten en vervolgens hun beslissingen kunnen verantwoorden ten overstaan van anderen.

Kortom: voor de beoordeling van professionaliteit is het van belang om te weten hoe iemand tot een bepaalde handeling gekomen is. Niet het wat, maar het hoe en waarom is daarbij belangrijk. De professional zal zich in zijn keuze of beslissing vervolgens moeten verantwoorden in het licht van bestaande opvattingen. Professionele integriteit betekent daarom niet zozeer dat men vasthoudt aan absolute persoonlijke normen en waarden, maar dat men in staat is zich te verantwoorden voor zijn keuzes in het licht van publieke, professionele en persoonlijke normen en waarden. ${ }^{10}$ Een professional kan uitleggen waarom juist hij of zij in dít geval voor díe persoon déze verantwoordelijkheden draagt. Dit verantwoorden gaat verder dan het verwijzen naar professionele ethische waarden en normen. Ook 'evidencebased' werken, goed communiceren met de patiënt, rekening houden met de sociale context waarin patiëntenzorg wordt gegeven - het zijn allemaal elementen van het normatieve verwachtingspatroon rond het professioneel handelen van de arts.

\section{Scholing en toetsing}

De professionele arts is iemand die de goede dingen op een goede manier doet. ${ }^{12}$ Daarmee is professionaliteit een tweede orde competentie - een competentie die alleen in de uitoefening van andere competenties tot uitdrukking kan komen. ${ }^{13}$ Anders gezegd, de arts als professional is in staat beslissingen inzake patiëntenzorg te verantwoorden binnen de gegeven context en professionele omgeving, inclusief de rollen en taakverantwoordelijkheden daarin. Tegelijkertijd willen we - met het CCMS - vasthouden aan het idee dat professionaliteit als een apart onderwijs- en toetsbaar competentiegebied is op te vatten. Kerncompetenties zijn daarbij reflectie en verantwoording.

Reflectie, omdat professionaliteit naast een handelingscomponent ook een reflectieve component ('weten waarom je iets doet') blijkt te hebben. Professionals moeten zich bewust zijn van wie ze zijn en vanuit welke positie zij spreken en handelen. Dit is een noodzakelijke voorwaarde voor het verantwoorden, wat plaatsvindt in een complexe praktijk ten overstaan van significante derden: patiënten, medebehandelaars, het team, de organisatie, de samenleving, et cetera. Kijkend naar de rollen die door het CCMS worden genoemd, dient een arts zich te verantwoorden in de rollen van medicus, communicator, samenwerker, wetenschapper, 'health advocate' en manager.

Voor de opleiding betekent deze visie op professionaliteit tenminste twee zaken: (a) onderwijs moet geïntegreerd plaatsvinden met andere competenties en (b) de opleiding moet niet primair gericht zijn op het voortbrengen van voorgeschreven 
handelingen, maar op het afleggen van verantwoording. Om dit te bereiken zijn verschillende instrumenten nodig, zoals analytische oefeningen in verantwoording, gesprekstechnieken ten behoeve van het expliciteren van veronderstelde professionaliteitsopvattingen en gestructureerde zelfreflectie. Binnen het Gronings Expertisecentrum Ethiek in de Zorg (EEZ) wordt daarom een mix van gerichte reflectieopdrachten (die zich richten op een bepaald aspect van de beroepspraktijk), alsmede expliciterende en oplossingsgerichte methodieken gehanteerd. Oplossingsgerichte methodieken - zoals bijvoorbeeld stappenplannen - zijn resultaatgericht; de uitkomst ervan is altijd een handelingsbesluit en de daarachterliggende rationale. Expliciterende methodieken richten zich veeleer op de professionaliteitsopvattingen die op de achtergrond sturend zijn voor het handelen. Voorbeelden zijn het klassieke socratische gesprek en de mede door het EEZ ontwikkelde Reflection Enhancement Tool (RET). ${ }^{14}$ Deze laatste methodiek richt zich expliciet op het helder krijgen van de invloed van omgevingsfactoren bij het tot stand komen van iemands professionele identiteit. De RET onderscheidt zich daarmee van alle andere methodieken die momenteel voorhanden zijn. Voor toetsing geldt dat er gebruik moet worden gemaakt van instrumenten die het vermogen van arts-assistenten beoordelen om zich te kunnen verantwoorden.

Het trainen en toetsen van professionaliteit is context-gebonden en zal ook vaak plaatsvinden in de alledaagse praktijk van de arts-assistent. Dit impliceert dat ook opleiders - zij beoordelen immers de competentie - bekwaam moeten zijn in het beoordelen van professionaliteit. Een scholingsprogramma in professionaliteit kan daarom niet zonder ook een training van opleiders in professionaliteit.

\section{Literatuur}

1. CCMS. De Algemene competenties van de medisch specialist [PDF-document op internet]. KNMG; 17 september 2004 [geciteerd op 2 juli 2005]. Beschikbaar op: http://knmg.artsennet.nl/uri/?uri=AMGATE_6059_100_TICH_ R1378461255090486.

2. Emanuel EJ, Emanuel LL. What is accountability in health care? Ann Intern Med 1996;124:229-39.

3. Oorschot JA, Jaspers Fr, Schaaf J, Linnebank F, Oostveen C, Braaksma J. Professionele autonomie van de medisch specialist. Assen: Van Gorcum; 1995.

4. Arnold R. Assessing professional behaviour: yesterday, today and tomorrow. Acad Med 2002;77:502-15.

5. Ginsburg S, Wagoner N, Regehr G, Hatala R, McNaughton N, Frohna A, et al. Context, conflict, and resolution: a new conceptual framework for evaluating professionalism. Acad Med 2000;75: s6-s11.

6. Projectteam Consilium Abeundi. Professioneel gedrag: onderwijs, toetsing, begeleiding en regelgeving. Utrecht: Projectteam Consilium Abeundi; 2002.

7. Harden RM, Crosby JR, Davis MH. Outcomebased education: Part 1. An introduction to outcome-based education. Med Teach 1999;21:7-14.

8. Ginsburg S, Regehr G, Lingard L. Basing the evaluation of professionalism on observable behaviors: a cautionary tale. Acad Med 2004;79:s1-s4.

9. Lynch DC, Surdyk PM. Assessing professionalism: a review of the literature. Med Teach 2004;26:36673.

10. Coulehan J, Williams PC. Conflicting professional values in medical education. Camb Q Healthc Ethics 2003;12:7-20.

11. Wear D, Kuczewski M. The professionalism movement: can we pause? Am J Bioeth 2004;4:1-10.

12. Verkerk MA. Ethiek en kwaliteitsbeleid. In: Slagter M, editor. De gepassioneerde professional. Assen: Van Gorcum; 2004. p. 9-16.

13. Harden RM, Crosby JR, Davis MH, Friedman M. AMEE Guide No.14: Outcome-based education: Part 5 - From competency to meta-competency: a model for the specification of learning outcomes. Med Teach 1999:21:546-52.

14. Verkerk M, Lindemann H, Maeckelberghe E, Feenstra E, Hartoungh R, Bree M de. Enhancing reflection: an interpersonal exercise in ethics education. The Hastings Cent Rep 2004;34:31-8.

* Dit artikel is een uitgebreide versie van: Verkerk MA, Bree M. de, Jaspers Fr. Visies op professioneel gedrag. Med Contact 2004;59:2035-7. 


\section{De auteurs:}

Mw. prof. dr. Marian Verkerk is hoogleraar Zorgethiek en hoofd Expertisecentrum Ethiek in de Zorg (EEZ) van het Universitair Medisch Centrum Groningen.

Drs. Menno de Bree is stafmedewerker van het Expertisecentrum Ethiek in de Zorg (EEZ) van het Universitair Medisch Centrum Groningen.

Drs. Frans Jaspers is lid van de raad van bestuur van het Universitair Medisch Centrum Groningen.

\section{Correspondentieadres:}

Mw. prof. dr. Marian Verkerk, UMCG, Expertisecentrum Ethiek in de Zorg, Postbus 30 001, 9700 RB Groningen, tel: 050-3637818,fax:050-3633059,m.a.verkerk@med. umcg.nl.

\section{Summary}

Residency training in the Netherlands will be restructured over the coming years. To this end a general competency profile for medical specialists will be used that closely resembles the roles and competencies developed by the Canadian Medical Education Directions for Specialists (CanMEDS) Project. One of the core competencies is professionalism. In order to establish a training programme for this competency, it is necessary to develop a view of professionalism that does justice to day-to-day medical practice. The two prevailing views of professionalism in the literature fail to do so, however. Only when professionalism is understood as reflective professionalism does it encompass the fundamental contextuality of medical treatment. This means that the focus of training and assessment must be shifted to specialists' accountability for their actions as professionals. (Verkerk MA, Bree M de, Jaspers Fr. Reflective professionalism. Towards an interpretation of 'professionalism' as defined by the Central College of Medical Specialisms (CCMS). Dutch Journal of Medical Education 2005;24(4):162-167.) 